\title{
Cymothoa indica (Isopoda; Cymothoidae) and Alitropus typus (Isopoda; Aegidae) on freshwater fish Tilapia mossambica (Cichlidae) in Vellar estuary, Southeast coast of India
}

\author{
G. Rameshkumar* \\ S. Ravichandran \\ Centre of Advanced Study in Marine Biology, Annamalai University \\ Parangipettai 608502, Tamil Nadu, Índia \\ *Corresponding author \\ grkumarcas@gmail.com
}

Submetido em 01/02/2010

Aceito para publicação em 24/06/2010

\begin{abstract}
Resumo
Parasitismo de Cymothoa indica (Isopoda; Cymothoidae) e Alitropus typus (Isopoda; Aegidae) sobre o peixe de água doce Tilapia mossambica (Cichlidae) no estuário do rio Vellar, costa sudeste da Índia. $\mathrm{O}$ estudo foi realizado com o objetivo de estabelecer a extensão de um duplo parasitismo dos isópodos Cymothoa indica e Alitropus typus sobre Tilapia mossambica. Cymothoa indica, um gênero típico da região Indo-Pacífica, e A. typus, um crustáceo parasita de peixes no sudeste da Ásia, que se alimenta sugando sangue, são relatados pela primeira vez parasitando Tilapia mossambica de água doce do estuário do Vellar.
\end{abstract}

Unitermos: estuário do rio Vellar, isopodes parasitas, registro de novos hospedeiros, Tilapia mossambica

\section{Abstract}

The study was carried out to establish the extent of double parasitation of two species of isopods Cymothoa indica and Alitropus typus on Tilapia mossambica. Cymothoa indica, a typical Indo-Pacific genus, and A. typus, a common crustacean parasite of fish in Southeast Asia, which feeds by sucking blood species, are reported by the first time in the freshwater fish Tilapia from Vellar estuary.

Key words: isopod parasite, new host records, Tilapia mossambica, Vellar estuary

\section{Introduction}

Parasitic diseases in fishes seriously limit aquaculture production and its economic viability. Knowledge of fish diseases and parasites is essential for successful aquaculture, particularly in a country like India with long and highly productive coastal waters. However, the tropical coastal and brackish waters, which likely contain many unknown parasites and pathogens, are poorly studied. Parasites play a pivotal role in the biology of fishes and can affect their behaviour, health and distribution (Rohde, 1993).

Many species of fish are infected by cymothoids (Crustacea, Isopoda, Cymothoidae). They are bloodfeeding; several species settle in the buccal cavity of fish, 
others live in the gill chamber or on the body surface including the fins. Their life cycle involves only one host (Holoxenic cycle). The pathological conditions resulting from parasitic infection often reach a significant extent under both natural and controlled conditions in aquaculture. The commercial aspects of harvesting fishes and crustaceans are greatly influenced by the presence of parasitic isopods on these hosts. As fish and decapod farming become more widespread, the effects of parasitic isopods should become more apparent (Kabata, 1984).

Studies of parasitic cymothoids in aquaculture systems are thus important not only for aquaculture development, but also as studies about interactions between the parasite and wild fishes. In the present study, C. indica (Schioedte and Meinert, 1884) and A. typus (Milne-Edwards, 1840) is reported for the first time double parasitizing in the body surface and buccal cavity in fresh water fish T. mossambica (Figure 1).

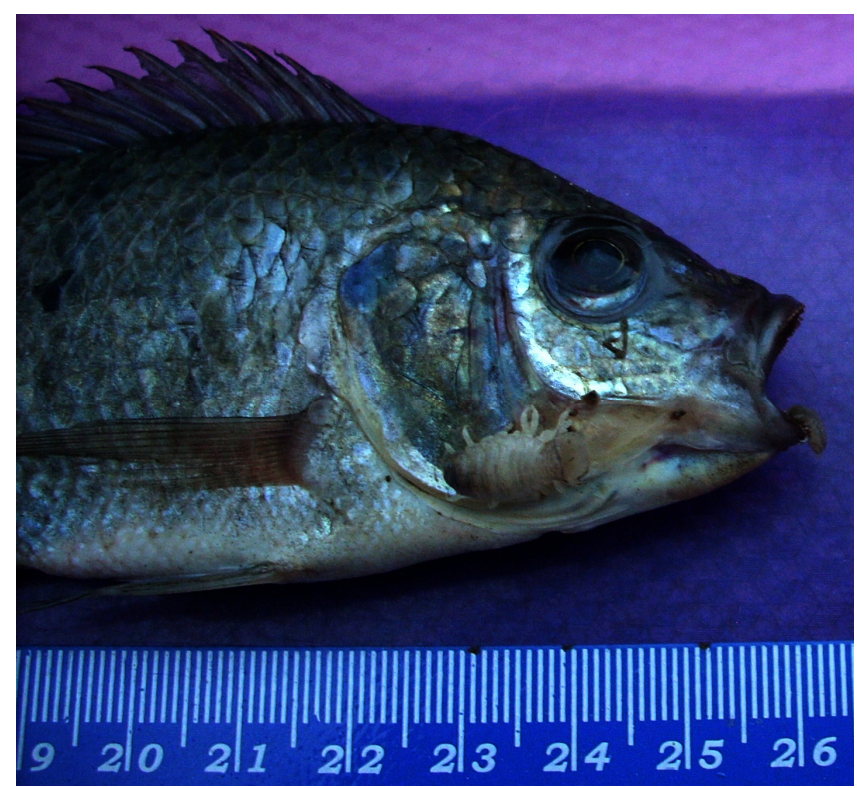

FIGURE 1: Cymothoa indica (1) attach to the body surface and Alitropus typus (2) settled on buccal region of the $T$. mossambica (scale in $12.8 \mathrm{~cm}$ ).

\section{Materials and Methods}

All the fish specimens were collected from the Vellar estuarine environment (Lat. $11^{\circ} 29^{\prime} \mathrm{N}$; $79^{\circ} 46^{\prime} \mathrm{E}$ ) from the local fisherman net. All collected specimens were immediately fixed in $70 \%$ ethanol and labeled. $C$. indica and A. typus were identified according to (MilneEdwards, 1840; Schioedte and Meinert, 1884; Pillai, 1954; Trilles, 1975; Veerapan and Ravichandran, 2000). Fishes were identified according to Froese and Pauly (2005). The work was carried out at CAS in Marine Biology, Annamalai University, Parangipettai, Tamil Nadu, India, in August 2009. The work carried out here is an occasional record and nearly 40 specimens of fishes were examined during the sampling time.

\section{Results}

During the Routine observation of T. mossambica fishery in Vellar estuary interestingly isopod parasite was observed in one fish. Two species of isopods were identified. They are $C$. indica (Schioedte and Meinert, 1884) (Crustacea; Isopoda; Cymothoidae) attached in body surface and A. typus (Milne-Edwards, 1840) (Aegidae; Isopoda; Malacostraca) attached in buccal region. A total of 40 fishes was investigated the study period one fish were infested.

According to the description of Trilles (1968; 1972), the cymothoid specimens were identified as Emetha audouini larvae, mainly a parasite of Sparidae and Centracanthidae on the western Mediterranean coasts and never before recovered from sea bass (Trilles, 1994). The parasites observed in the buccal cavities were removed and identified as $C$. indica according to (Trilles, 1975; Veerapan and Ravichandran, 2000). In all cases, the parasites had settled on the floor of the buccal cavity of the host and clung firmly to the tongue with their heads pointed in the anterior direction. The number of parasites on each fish ranged between 1 and 3 and was found to be alive as long as 5 to $6 \mathrm{~h}$ after the death of the host.

The body surface of the dying fish was covered and the buccal cavity filled with excessive mucus. Reddening of muscles around the site of infection and intense darkening of the body were also observed. The clinical signs included loss of condition, anorexia and erratic swimming behavior. No other parasitic organisms were observed that might be associated with such a disease. 


\section{Comments}

For the first time, $C$. indica is reported infecting freshwater fish in Vellar estuary. Veerapan and Ravichandran (2000) recorded a similar infection of the wild fishes Sphyraena obtusata and Rachinocephalus myops. Rajkumar et al. (2004) observed a severe parasitism by $C$. indica in the buccal cavity of the spot tail needlefish Strongylura strongylura.

Excessive mucus secretion by the infected fish is a host response evoked to overcome the irritation caused by the parasite and has already been noted as an accompanying sign in all diseases induced by parasitic. The nutritional aspect of the fish may be a influencing aspect in excess secretion of mucous with respect to the isopod and other parasitic infections (Verlhac and Gabaudan, 1994; Verlhac et al., 1995).

In aquaculture, examples of modified specificity are sometimes observed with some parasites (isopods, copepods, monogeneans); these parasites are never found to be present on the wild population of hosts whereas the reared individuals of the same species are infected (Raibaut et al., 1980; Euzet and Raibaut, 1985; Cabral and Raibaut, 1987; Cassier et al., 1998). But in the present investigation infestation and modified host specificity was recorded in the wild environment. In Greece, Ernetha audouini, mainly a parasite of Sparidae and Centracanthidae, transfers to Dicentrarchus labrax, whose wild populations are never parasitized. This case of specificity, modified and extended, is very interesting since it is the second case observed in the family Cymothoidae and proves the possibility of such parasitic diseases in aquaculture and it is the first case observed involving buccal cymothoids.

The methods that should be applied in the future for prophylaxis of this kind of parasitic problems, which can cause great mortalities and compromise the production of fishes, are immunization and the selection of resistant individuals via genetic manipulation. Prevention is the best means to control crustacean fish parasites. Crustacean fish parasites are difficult to remove from fish culture facilities. Adult stages of these organisms are generally no more affected by chemical treatments than is the host. Attempts to eliminate the parasites may also damage the host fish.

\section{Acknowledgement}

Authors are thankful to Department of Science and Technology, Government of India for providing financial support and Dr. T. Balasubramanian, Director of CAS in Marine Biology for providing facilities and encouragement.

\section{References}

Cabral, P.; Raibaut, A. 1987. Découverte d'un Copépode Caligide nouveau parasite du tégument du loup Dicentrarchus labrax (L., 1758) (Pisces, Moronidae) en élevage et enmilieu naturel. Bulletin de la Societe Zoologique de France, 111 (1-2): 123-130.

Cassier, P.; Brugerolle, G.; Combes, C.; Grain, J.; Raibaut, A. 1998. Le parasitisme. Un équilibre dynamique. Masson, Paris, France, 420pp.

Euzet, L.; Raibaut, A. 1985. Les maladies parasitaires en pisciculture marine. Symbioses, 17: 51-68.

Froese, R.; Pauly, D. 2005. Fish base. World Wide Web electronic publication. Available at $<$ http://www.fishbase.org $>$. Accessed on May, 2005.

Kabata, Z. 1984. Diseases caused by metazoans: Crustaceans. In: Kinne, O. (Ed.). Diseases of marine animals. IV (I). Biologische Anstatt Helgoland, Hamburg, Germany, p.321-399.

Milne Edwards, H. 1840. Histoire naturelle des crustacés comprenant l'anatomie, la physiologie et la classification de ces animaux. V.III. Librairie Encyclopédique deRoret, Paris, France, 468pp.

Pillai, N. K. 1954. A preliminary note on the Tanaidacea and Isopoda of Travancore. Bulletin of the Central Research Institute, University of Kerala, Trivandrum, India, Ser. C, Natural Sciences, 3: 1- 21.

Raibaut, A.; Divanach, P.; Coste, F.; Maillard, C. 1980. Copépodose larvaire en écloserie de poissons marins. La Piscicult France, 61/62: 49-51.

Rajkumar, M.; Santhanam, P.; Perumal, P. 2004. Report on new host record of Cymothoa indica (Schioedte and Meinert, 1884) (Crustacea: Isopoda) from Parangipettai coastal waters, southeast coast of India. Journals of Aquatic Biology, 19 (2): 113-114.

Rohde, K. 1993. Ecology of marine parasites. $2^{\text {nd }}$ ed. CAB International, Wallingford, USA, 297pp.

Schioedte, J. C. ; Meinert, F. 1884. Symbolae ad monographiam Cymothoarum Crustaceorum Isopodum familiae. IV. Cymothoidae, Trib. II. Cymothoinae. Trib. III. Livonecinae. Naturhistorisk Tidsskrift, 14: 221-454.

Trilles, J. P. 1968. Recherches sur les Isopodes Cymothoidae des cBtes franqaises. $2^{\text {nd }} \mathrm{PhD}$ Thesis, University of Montpellier I1, France, 181pp.

Trilles, J. P. 1972. Les Cymothoidae (Isopoda, Flabellifera) des cBtes franqaises (systematique, faunistique, ecologie et repartition geographique). I. Les Ceratothoinae Schioedte et Meinert, 1883. Bulletin du Museum National Paris Zoologique, 70: 1191-1230. 
Trilles, J. P. 1975. Les Cymothoidae (Isopoda, Flabellifera) des collections du Muséum National d'Histoire Naturelle de Paris. III. Les Cymothoidae Schioedte et Meinert, 1884. Genre Cymothoa Fabricius, 1787. Bulletin du Museum National de Histoire Naturelle, 318 : 977-993.

Trilles, J. P. 1994. Les Cymothoidae (Crustacea, Isopoda) du Monde (Prodrome pour une faune). Studia Marina, 21/22: 1-2.

Veerapan, N.; Ravichandran, S. 2000. Isopod parasites from marine fishes of Parangipettai coast. UGC-SAP Monograph Series, Annamalai University, Parangipettai, India, 24pp.

Verlhac, V.; Gabaudan, J. 1994. Influence of vitamin C on the immune system of salmonids. Aquaculture and Fish Management, 25: 21-36.

Verlhac, V.; Gabaudan, J.; Schuep, W. 1995. Immuno modulation in fish: II. Effect of dietary vitamin C. Proceedings of the $2^{\text {nd }}$ Roche Aquaculture Centre Conference on Nutrition and Disease, Bangkok, Thailand, p 53-58. 